\title{
Effects of attached bacteria on organic aggregate settling velocity in seawater
}

\author{
Yosuke Yamada, Hideki Fukuda, Katsuyuki Inoue, Kazuhiro Kogure, Toshi Nagata*
}

Atmosphere and Ocean Research Institute, The University of Tokyo, 5-1-5, Kashiwanoha, Kashiwa-shi, Chiba 277-8564 Japan

\begin{abstract}
We investigated whether attached bacteria affect the settling velocity of organic aggregates via modifications of the physical properties of aggregates, including density, porosity, and morphology. Model aggregates, prepared by mixing 2 different polysaccharides (fucoidan and chitosan), were incubated in coastal seawater passed through either $0.8 \mu \mathrm{m}\left(\mathrm{AGG}_{0.8}\right)$ or $0.2 \mu \mathrm{m}\left(\mathrm{AGG}_{0.2}\right)$ filters. After incubation for $48 \mathrm{~h}, \mathrm{AGG}_{0.8}$ were much more densely (3.2- to 10.1fold) colonized by bacteria than $\mathrm{AGG}_{0.2}$. Based on median settling velocities $\left(W_{50}\right)$, as determined by laser in situ scattering and transmissometry, the $W_{50}$ of $\mathrm{AGG}_{0.8}$ was lower (1.6- to 4.5 -fold) than that of $\mathrm{AGG}_{0.2}$ for a size class of 62 to $119 \mu \mathrm{m}$. Stokes model analyses indicated that this reduction in $W_{50}$ could be largely attributed to the higher porosities of $\mathrm{AGG}_{0.8}(0.932-0.981)$ than those of $\mathrm{AGG}_{0.2}(0.719-0.929)$. Our results support the notion that the modification of aggregate structure by attached bacteria (porosity enhancement) can be an important factor controlling the settling velocity of marine particles.
\end{abstract}

KEY WORDS: Bacteria $\cdot$ Aggregate $\cdot$ Settling velocity $\cdot$ Porosity $\cdot$ Marine environments

\section{INTRODUCTION}

Organic aggregates, including transparent exopolymer particles (TEP) and hydrogels, play an important role in the regulation of material cycling and food webs in marine ecosystems (Alldredge 1979, Simon et al. 2002, Verdugo 2012). Organic aggregate settling from the sunlit layer to the deeper layers of the oceans mediates the vertical delivery of organic carbon and other bioelements, representing an important regulatory element of carbon sequestration (Fisher et al. 1991, Passow \& De La Rocha 2006, De La Rocha \& Passow 2007) and a means of energy and nutrient supply to heterotrophic organisms in aphotic layers and on the seafloor (Alldredge 1979, Grossart et al. 1998, Passow et al. 2001). Because the settling velocity of aggregates is a key variable that influences the length-scale of vertical carbon delivery and remineralization depth (Passow \& Carlson 2012), it is important to clarify the variability and control of aggregate settling velocities in marine environments.

${ }^{*}$ Corresponding author. Email: nagata@aori.u-tokyo.ac.jp
Aggregate settling velocity is affected by the physical properties of aggregates including size, porosity, morphology, and association with ballast particles such as diatom frustules and coccolith shells (Ploug et al. 2008, Iversen \& Ploug 2010). These aggregate properties may reflect not only the composition of, and physicochemical interactions among, polymeric materials and other constituents (Chin et al. 1998, Verdugo 2012) but also the modification of aggregate structures by attached microbes. Bacteria can actively proliferate on the surface and in the interstitial spaces of aggregate matrices, cleaving polymer chains to create pores and reduce aggregate size (Passow \& Alldredge 1994, Azam \& Malfatti 2007). Alternatively, bacteria may excrete sticky polymeric materials to fill interstitial spaces and promote aggregate production (Cowen 1992, Stoderegger \& Herndl 1998, Sugimoto et al. 2007). Furthermore, the replacement of aggregate matrices by bacterial cells may alter bulk aggregate density. However, the prevailing mode and net outcome of these complex bac-

() The authors 2013. Open Access under Creative Commons by Attribution Licence. Use, distribution and reproduction are unrestricted. Authors and original publication must be credited. 
terial actions in controlling organic aggregate settling velocities in seawater are not entirely clear.

To understand how bacterial modification of the physical properties of aggregates affects aggregate settling velocities, we examined the settling velocities of model aggregates with different degrees of bacterial colonization. Data on the physical parameters of aggregates, including size, porosity, and morphology, were collected to investigate the dominant mechanism by which attached bacteria affect the settling velocities of organic aggregates in marine environments.

\section{MATERIALS AND METHODS}

\section{Preparation of model aggregates}

We used compositionally defined, spontaneously assembled gels (Verdugo 2012) as model aggregates to investigate bacterial effects on aggregate settling velocity with minimal effects of compositional variability of organic aggregates in natural environments (see 'Discussion'). The model aggregates were prepared using fucoidan (a sulfated polysaccharide found in brown seaweed) and chitosan (a partially deacetylated derivative of the amino polysaccharide, chitin) according to a gel preparation protocol originally developed by Nakamura et al. (2008) for pharmaceutical purposes. Fucoidan was extracted from Kjellmanialla crassifolia (Gagomekombu) according to Nakamura et al. (2008). Gagome-kombu powder (10 g) (Toyonaka Matumae Konbu Honpo Corp., Osaka, www.kobuya.net) was added to $100 \mathrm{ml} 70 \%$ by volume ratio (v/v) ethanol containing $0.1 \mathrm{M}$ acetic acid in a $200 \mathrm{ml}$ conical glass flask. After gentle mixing, the suspension was filtered through polycarbonate filters $(10 \mu \mathrm{m}$ pore size, $47 \mathrm{~mm}$ diameter; Whatman). The filtrate was air-dried and added to $200 \mathrm{ml} 8.8 \mu \mathrm{M} \mathrm{CaCl}_{2}$ solution. After boiling for $30 \mathrm{~min}$, the extract was centrifuged $(2330 \times g)$ at room temperature for $10 \mathrm{~min}$. The supernatant was filtered through polycarbonate filters (10 $\mu \mathrm{m}$ pore size, $47 \mathrm{~mm}$ diameter; Whatman). The filtrate was mixed with $2 \times$ volume of $99.5 \%$ ethanol (total volume, ca. $300 \mathrm{ml}$ ). The precipitated materials were collected on polycarbonate filters (10 $\mu \mathrm{m}$ pore size, $47 \mathrm{~mm}$ diameter; Whatman) and transferred to a $500 \mathrm{ml}$ conical glass flask. The increasing volumes of $\mathrm{NaCl}$ solution $(0.9 \%$ by weight to volume ratio [wt/vol], containing $10 \mathrm{mM}$ EDTA-2Na) were slowly added to the precipitates until the mixture became clear (the total volume of
$\mathrm{NaCl}$ solution added was ca. $75 \mathrm{ml}$ ). Precipitates that were not completely dissolved were eliminated by successive filtration through 2 types of glass fiber filter (GF/D and GF/C filters, $47 \mathrm{~mm}$ diameter; Whatman) and polycarbonate filters $(0.8 \mu \mathrm{m}$ pore size, $47 \mathrm{~mm}$ diameter; Whatman). The filtrate was mixed with $2 \times$ volumes of $99.5 \%$ ethanol (total volume: ca. $150 \mathrm{ml})$ and centrifuged $(2330 \times g)$ at room temperature for $10 \mathrm{~min}$. Finally, the precipitates (fucoidan extracts) were broken into small pieces with spatulas and air-dried in a flow hood. Fucoidan solution $(2.1 \% \mathrm{wt} / \mathrm{vol})$ was prepared by dissolving $16.6 \mathrm{mg}$ fucoidan extract in $790 \mu \mathrm{l}$ Milli-Q water (Millipore). Chitosan solution (3.8\% $\left.\mathrm{w} \mathrm{v}^{-1}\right)$ was prepared by dissolving $1.25 \mathrm{~g}$ chitosan (LL-40, Yaizu Suisankagaku Industry, extracted from Chionoecetes opilo; nominal deacetylation rate: $>80 \%$ ) in $33.1 \mathrm{ml} 190 \mathrm{mM} \mathrm{HCl}$.

Model aggregates were prepared by mixing chitosan and fucoidan solutions according to Nakamura et al. (2008) with the following modifications. Before the preparation of aggregates, chitosan and fucoidan solutions (see above) were centrifuged at $1200 \times g$ for $10 \mathrm{~min}$ at $23^{\circ} \mathrm{C}$. The supernatant of each solution was successively filtered through $0.8 \mu \mathrm{m}$ and $0.2 \mu \mathrm{m}$ syringe filters $(25 \mathrm{~mm}$ diameter, Acrodisc syringe filter with Supor ${ }^{\circledR}$ membrane; Pall) to remove particles. Then, $210 \mu \mathrm{l}$ chitosan solution was added to $50 \mathrm{ml}$ filtered $(0.2 \mu \mathrm{m})$ seawater in a $50 \mathrm{ml}$ polypropylene tube (BD Falcon Conical Centrifuge tube; Fisher Scientific). After gentle mixing, $790 \mu \mathrm{l}$ clear fucoidan solution was added to the seawater and then mixed. At this stage, the formation of aggregates was observed. After storage of the suspension at $4^{\circ} \mathrm{C}$ for $3 \mathrm{~h}$, aggregates that settled at the bottom of the tube were collected by removing the supernatant by aspiration ( $10 \mathrm{ml}$ solution remaining). Then, $40 \mathrm{ml}$ of the filtered $(0.2 \mu \mathrm{m})$ seawater was added to the tube. The aggregate suspension was filtered through a nylon mesh (Nitex screen, mesh size $200 \mu \mathrm{m}$; Wildlife Supply Company) to remove large aggregates. The aggregate suspension (hereafter, $50 \mathrm{ml}$ working suspension) was stored at $4^{\circ} \mathrm{C}$ for $3 \mathrm{~h}$ until it was used for the settling velocity experiments.

\section{Collection of seawater samples and incubation of model aggregates}

Surface seawater samples were collected using a plastic bucket at the shore of Oarai Beach, Ibaraki, Japan $\left(36^{\circ} 19^{\prime} 3^{\prime \prime} \mathrm{N}, 140^{\circ} 35^{\prime} 29^{\prime} \mathrm{E}\right)$, on January 30 (water temperature: $10.1^{\circ} \mathrm{C}$, salinity: 29.2), August 29 
$\left(24.0^{\circ} \mathrm{C}, 29.2\right)$, and November $15\left(17.3^{\circ} \mathrm{C}, 28.8\right), 2011$. Within $12 \mathrm{~h}$ of sampling, seawater samples were filtered through $0.8 \mu \mathrm{m}$ polycarbonate filters $(47 \mathrm{~mm}$ diameter; Whatman) to eliminate grazers and other eukaryotes. The filtrate was further filtered through $0.2 \mu \mathrm{m}$ polycarbonate filters $(47 \mathrm{~mm}$ diameter; Whatman) using negative pressure $(<20 \mathrm{mmHg})$ to reduce the abundance of bacteria and minimize their effects on aggregate properties.

The $50 \mathrm{ml}$ working suspension of aggregates and $500 \mu \mathrm{l}$ autoclaved $20 \mathrm{mM} \mathrm{Na} \mathrm{HPO}_{4}$ solution were added to three $500 \mathrm{ml}$ polycarbonate bottles (Nalgene; Nalge Nunc International) filled with $450 \mathrm{ml}$ seawater (filtered at $0.8 \mu \mathrm{m}$ or $0.2 \mu \mathrm{m}$ ). After incubation for $48 \mathrm{~h}$ at $23^{\circ} \mathrm{C}$ in the dark using an incubation shaker (TA-20RLS, Takasaki Scientific Instruments; shaking speed: $100 \mathrm{rpm})$, both aggregate preparations (those obtained from $0.8 \mu \mathrm{m}$ and $0.2 \mu \mathrm{m}$ filtration; hereafter, $\mathrm{AGG}_{0.8}$ and $\mathrm{AGG}_{0.2 \text {, }}$ respectively) were used for the determination of aggregate settling velocities and the characterization of aggregate properties.

\section{Microscopic examination of aggregates and attached bacteria}

Aggregate samples were fixed with $0.2 \mu \mathrm{m}$ filtered $2 \% \mathrm{v} / \mathrm{v}$ (final concentration) glutaraldehyde $(20 \%$ glutaraldehyde; Wako). In the January experiment, the aggregate size and abundance of attached bacteria were determined after SYBR Gold-Alcian Blue double staining (Sugimoto et al. 2007). Seawater samples were filtered through $0.02 \mu \mathrm{m}$ aluminosilicate filters (25 mm diameter; Whatman). Filters were stained with $1 \% \mathrm{wt} / \mathrm{vol}$ Alcian Blue $\left(8 \mathrm{GX}_{i}\right.$ SigmaAldrich) dissolved in 3\% v/v acetic acid (Logan et al. $1994)$ and then stained with SYBR Green I (0.25\% $\mathrm{v} / \mathrm{v}$, in a ratio of 1:400 of the supplied concentration diluted with Milli-Q filtered at $0.2 \mu \mathrm{m}$; Molecular Probes; Noble \& Fuhrman 1998) for $10 \mathrm{~min}$. The filters were mounted on slides using immersion oil (nd = 1.516; Olympus) and observed under an epifluorescence microscope $(\times 1000, \mathrm{BX} 61$; Olympus $)$. Alcian Blue-stained aggregate images observed under the transmitted illumination were captured using a charge-coupled device camera (Olympus DP70; Olympus). The area and morphological features of aggregates (the ratio of long axis to short axis and the circularity) were analyzed using Image J software (v. 1.45 with Java, 1.6.0_20). The area was converted into the equivalent spherical diameter (ESD), allowing it to be classified into 5 size classes: $62 \mu \mathrm{m}$
(56-66 $\mu \mathrm{m}), 73 \mu \mathrm{m}(67-78 \mu \mathrm{m}), 86 \mu \mathrm{m}(79-92 \mu \mathrm{m})$, $101 \mu \mathrm{m}(93-109 \mu \mathrm{m})$, and $119 \mu \mathrm{m}(110-129 \mu \mathrm{m})$. Bacteria attached to the aggregates were counted using the epifluorescence optics optimized for SYBR Green I (filter set, U-MNIB2; Olympus). After imaging, the volumes of bacteria $\left(\mu^{3}\right)$ attached to aggregates were determined for $\mathrm{AGG}_{0.8}$ and $\mathrm{AGG}_{0.2}$ from both their area and perimeter using ImageJ software (Massana et al. 1997).

In the August and November experiments, the abundance of attached bacteria was determined by the 4',6-diamidino-2-phenylindole (DAPI) staining method (Porter \& Feig 1980). Samples were filtered through $12 \mu \mathrm{m}$ polycarbonate filters $(25 \mathrm{~mm}$ diameter, Whatman) with a vacuum of $<20 \mathrm{~mm} \mathrm{Hg}$. The filters were stained with DAPI $\left(1 \mu \mathrm{g} \mathrm{ml}^{-1}\right)$ for $5 \mathrm{~min}$, mounted on slides using immersion oil (Vectashield, from Vector Laboratories, and from Citifluor Limited), and observed under an epifluorescence microscope $(\times 1000$, BX61, Olympus) equipped with epifluorescence optics optimized for DAPI (filter set, U-MWU2, Olympus). The sizes of aggregates, detected as pale-yellow objects, were manually determined using a grid ocular micrometer and classified into the 5 size classes described above.

\section{Abundance, size, and settling velocity of aggregates}

Particle size distribution and particle volumes were measured by laser in situ scattering and transmissometry (LISST, LISST-100X, Sequoia Scientific; Agrawal \& Pottsmith 2000) (hereafter, aggregate 'size' refers to the ESD of the aggregate). The settling velocities of aggregates were determined using a settling column (300 $\mathrm{ml}$ volume, $15 \mathrm{~cm}$ travel path) attached to the chamber of the LISST-100X (Small Volume Horizontal Test Chamber; Sequoia Scientific) (Agrawal \& Pottsmith 2000). The aggregate settling velocity was estimated from the decrease in aggregate abundance over time. The aggregate abundance data were collected every $30 \mathrm{~s}$ (up to $3 \mathrm{~h}$ ) for each size class (the numbers of aggregates counted at time zero were 841 to 21693 for each size class) to determine the time ( $T_{\mathrm{h}}$, in seconds) at which the aggregate abundance became half of the initial aggregate abundance for a given size class. Then, the median settling velocity $\left(W_{50}, \mathrm{~cm} \mathrm{~s}^{-1}\right.$, Owen 1971) was calculated by dividing the travel path $(15 \mathrm{~cm}$, the distance between the surface of sample seawater and the horizontal position of the LISST detector) by $T_{\mathrm{h}}$ (range: 900-8060 s). 


\section{Density of attached bacteria}

In the August experiment, the density distribution of bacteria attached to aggregates (after $48 \mathrm{~h}$ incubation) was measured according to Inoue et al. (2007). To remove attached bacteria from aggregate matrices, aggregate structures were mechanically destroyed by filtration through a $0.8 \mu \mathrm{m}$ syringe filter (25 mm diameter; Pall). First, $2 \mathrm{ml} \mathrm{AGG}_{0.8}$ was filtered through the syringe filter, and the filtrate was discarded (we assumed that bacteria collected on the $0.8 \mu \mathrm{m}$ filter represented those associated with $\mathrm{AGG}_{0.8}$, although some attached bacteria might have passed through the filters). Then, $2 \mathrm{ml}$ filtered seawater $(0.2 \mu \mathrm{m})$ was passed through the same syringe filter. The filtrate was passed a second time through the same syringe filter. This operation was repeated 10 times to obtain a bacterial suspension. The recovery of attached bacteria was calculated as follows: (bacterial abundance determined for the bacterial suspension obtained after aggregate mechanical destruction) / (attached bacterial abundance initially determined using the $0.8 \mu \mathrm{m}$ pore size filters) $\times 100$. Bacteria were enumerated by the DAPI staining method as described in 'Microscopic examination of aggregates and attached bacteria'. The recovery was $102.1 \pm 16.8 \%$ (mean \pm standard error [SE], $\mathrm{n}=7$ ).

To determine attached bacterial density, $1 \mathrm{ml}$ attached bacterial suspension and a $0.1 \mathrm{ml}$ solution of density marker beads (Amersham Biosciences) were layered on top of $9 \mathrm{ml}$ Percoll gradient working solution. The working solution consisted of $30 \%$ v/v Percoll, $10 \%$ v/v of $10 \times$ phosphatebuffered saline ( $\mathrm{pH} 7.4), 2.34 \% \mathrm{wt} / \mathrm{vol}$ of $\mathrm{NaCl}$ and autoclaved Milli-Q (filtered through the $0.2 \mu \mathrm{m}$ pore size filter) and was contained in a centrifugation tube (No. 7031; Seton Scientific). Then, the tube was ultra-centrifuged $(50512 \times g)$ for $20 \mathrm{~min}$ at $20^{\circ} \mathrm{C}$ (Optima XL-90 with SW40Ti rotor; Beckman Coulter). After centrifugation, the tubes were marked at equal distances from the surface layer of the solution to the bottom to divide it into 10 fractions. Then, $1 \mathrm{ml}$ solution was withdrawn at each mark position, in descending order, by pricking the centrifugation tube wall with a $1 \mathrm{ml}$ syringe with a needle $(0.45 \times 13 \mathrm{~mm} ;$ Terumo). The bacterial abundance in each fraction was counted by epifluorescence microscopy $(\times 1000, \mathrm{BX} 61$; Olympus $)$ after DAPI staining. Bacteria recovered in the top and bottom fractions contained bacteria with densities either lower $\left(<1.033 \mathrm{~g} \mathrm{~cm}^{-3}\right)$ or higher $(>1.086 \mathrm{~g}$ $\mathrm{cm}^{-3}$ ) than the analytical limits of the present method. For the calculation of the weighted average density of the total attached bacterial assemblage, we assumed that the densities of bacteria collected in the top and bottom fractions were 1.033 and $1.086 \mathrm{~g} \mathrm{~cm}^{-3}$, respectively.

\section{Aggregate porosity}

The porosities of $\mathrm{AGG}_{0.2}$ and $\mathrm{AGG}_{0.8}$ obtained in the November experiment were estimated by comparing aggregate size distributions determined by LISST to those determined using a resistive pulse particle counter (Coulter counter; Multisizer II, Beckman Coulter) (Sterling et al. 2004). This method is based on different principles of 2 instruments to measure particle size distributions. LISST measures light scattering of particles (reflecting particle bulk volume), whereas a Coulter counter determines the electric resistance of particles (reflecting particle solid volume). For porous particles, the particle size distribution determined by a Coulter counter deviates to smaller size categories relative to that determined by LISST, reflecting the degree of porosity (Sterling et al. 2004). We used the following equation to derive the index of porosity $(\varepsilon)$ :

$$
\operatorname{Porosity}(\varepsilon)=1-\frac{V_{\mathrm{C}}}{V_{\mathrm{L}}}
$$

where $V_{\mathrm{C}}$ and $V_{\mathrm{L}}$ are the volume of aggregates (ml aggregate $^{-1}$ ) determined by the Coulter counter and LISST, respectively. $V_{\mathrm{C}}$ and $V_{\mathrm{L}}$ for each size class were estimated from the Coulter-based aggregate diameter $\left(D_{\mathrm{C}}\right)$ and LISST-based diameter $\left(D_{\mathrm{L}}\right)$, assuming that the aggregates were spheres. Because the bins differed between $D_{\mathrm{C}}$ and $D_{\mathrm{L}}$, we derived the abundance- $D_{\mathrm{L}}$ regression (log-log regression) for the LISST data to estimate the aggregate abundance $\left(\mathrm{l}^{-1} \mathrm{\mu m}^{-1}\right)$ for the size category between $62 \mu \mathrm{m}\left(N_{62}\right)$ and $119 \mu \mathrm{m}\left(N_{119}\right)$. Then, $D_{C}$ for the abundance range between $N_{62}$ and $N_{119}$ was compared to the $D_{\mathrm{L}}$ (derived from the abundance- $D_{\mathrm{L}}$ regression) belonging to the same abundance category.

\section{Ectoenzymatic activity}

In the August experiment, the activity of the bacterial ectoenzyme that potentially hydrolyzes aggregate polymer constituents (chitosan) was determined using a methylumbelliferyl (MUF) substrate, 
4-MUF- $N$-acetyl- $\beta$-D-glucosaminide (Sigma-Aldrich) (Hoppe 1983). Fluorescent substrate dissolved in 2methoxyethanol was added to either total or syringefiltered $(0.8 \mu \mathrm{m})$ sample waters (final conc. $0.05 \mathrm{mM}$ ). The samples were incubated at $23^{\circ} \mathrm{C}$ for $2 \mathrm{~min}$. After adding borate buffer $(0.5 \mathrm{M}$ boric acid with $\mathrm{NaOH}$, $\mathrm{pH}$ 10), fluorescence (455 nm emission, $365 \mathrm{~nm}$ excitation) was determined using a fluorescence spectrophotometer (RF-1500; Shimadzu). The enzyme activity was calibrated using 4-methylumbelliferone (Sigma-Aldrich) as a standard. The enzyme activity associated with each aggregate $\left(\mathrm{AGG}_{0.2}\right.$ and $\left.\mathrm{AGG}_{0.8}\right)$ was estimated by subtracting the enzyme activity determined for filtered samples from that determined for the total sample.

\section{RESULTS}

\section{Aggregate size distribution and total volume}

After incubation for $48 \mathrm{~h}$, both $\mathrm{AGG}_{0.8}$ and $\mathrm{AGG}_{0.2}$ displayed a similar unimodal size distribution with a peak at $119 \mu \mathrm{m}$ in all experiments (Fig. 1). Total volume concentration of aggregates initially added was $97.5 \pm 4.3 \mathrm{ppm}$ (mean $\pm \mathrm{SE}, \mathrm{n}=22$ ), which was within the range of typical TEP volume concentrations reported in coastal waters (Passow 2002). Aggregates belonging to the 62 to $119 \mu \mathrm{m}$ size class were used to assess the effect of bacterial attachment on aggregate settling velocities. This size range was used because for smaller aggregates $(<62 \mu \mathrm{m}$ size class) the settling velocity was too low to be determined within the time frame of our measurement (up to $3 \mathrm{~h}$ ) and because LISST could not capture sufficient numbers of settling events for larger aggregates (>119 $\mu \mathrm{m}$ size class).

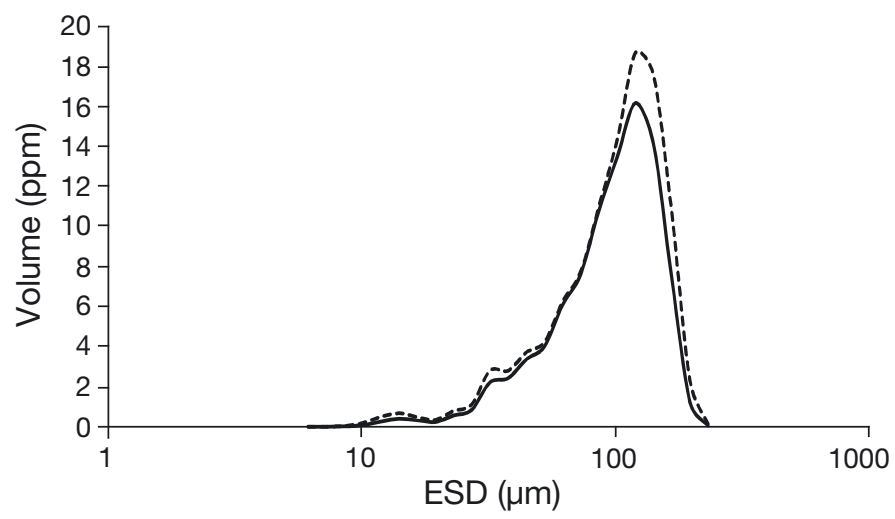

Fig. 1. Aggregate size (equivalent spherical diameter [ESD]) distribution for (solid line) $\mathrm{AGG}_{0.8}$ and (dashed line) $\mathrm{AGG}_{0.2}$. Data are from the August experiment

\section{Abundance and density of attached bacteria, and settling velocity}

Aggregates were porous (Fig. 2a), clearly stained by Alcian Blue (Fig. 2b), and associated with bacte-
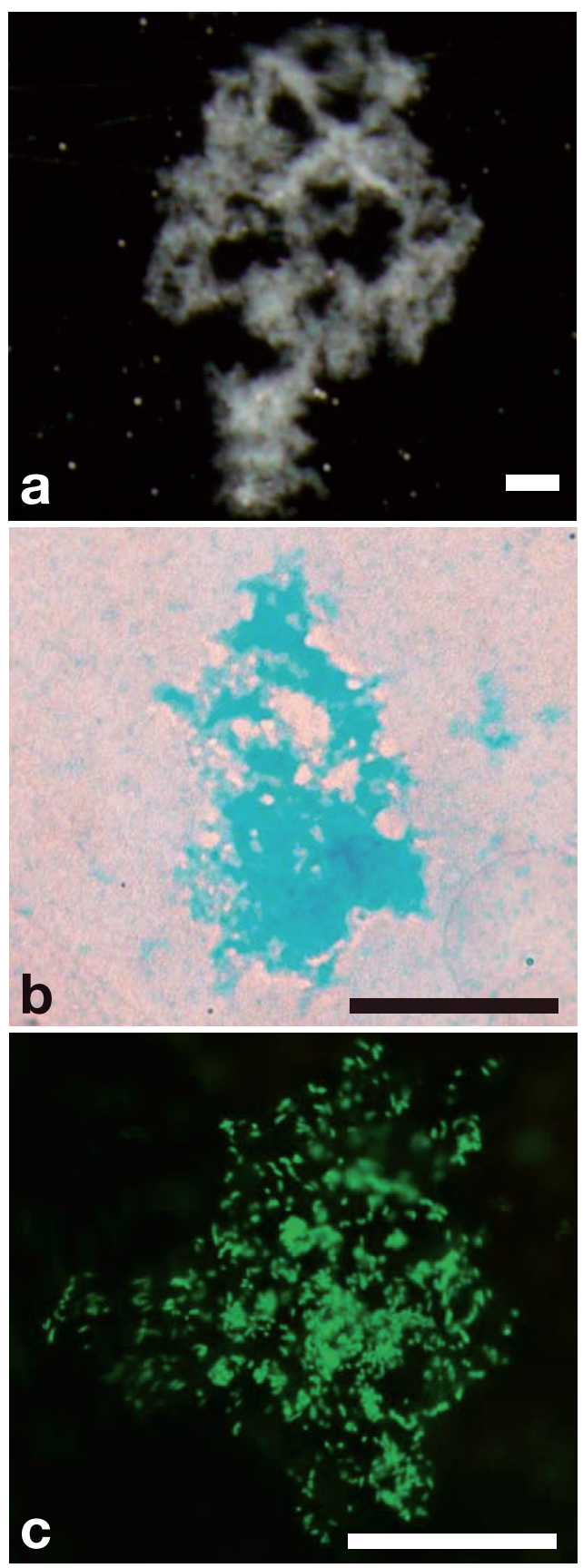

Fig. 2. Microscopic images of aggregate $\mathrm{AGG}_{0.8}$ (collected during the January experiment). Scale bars $=50 \mu \mathrm{m}$. (a) Transmission light microscopic image. (b) Transmission light microscopic image after Alcian Blue-SYBR Green I double staining. (c) Epifluorescence microscopic image after Alcian blue-SYBR Green I double staining. Green particles are bacteria 
ria (Fig. 2c). For both $\mathrm{AGG}_{0.2}$ and $\mathrm{AGG}_{0.8}$, bacterial abundance per aggregate generally increased with increasing aggregate size (Fig. 3). Empirical equations that relate attached bacterial abundance (ABA) to the diameter of aggregates $(D$ in $\mu \mathrm{m})$ were obtained using a linear regression model after a double logarithmic transformation. The following regression equations were derived: $\log \mathrm{ABA}=$ $-1.32+(2.31 \times \log D)\left(\mathrm{r}^{2}=0.98, \mathrm{p}<0.001, \mathrm{n}=15\right)$ for $\mathrm{AGG}_{0.8}$ and $\log \mathrm{ABA}=-1.51+(2.04 \times \log D)$ $\left(\mathrm{r}^{2}=0.57, \mathrm{p}<0.01, \mathrm{n}=15\right)$ for $\mathrm{AGG}_{0.2}$. For each size class, bacterial abundance associated with $\mathrm{AGG}_{0.8}$ was much higher (3.2- to 10.1-fold) than the corresponding value for $\mathrm{AGG}_{0.2}$. The differences in bacterial abundance between $\mathrm{AGG}_{0.8}$ and $\mathrm{AGG}_{0.2}$ were significant $(\mathrm{p}<0.01$, Student's $t$-test) for all size classes. In the January experiment, the average size of bacteria associated with $\mathrm{AGG}_{0.8}$ was $0.47 \pm$ $0.01 \mu^{3}$ (mean $\pm \mathrm{SE}, \mathrm{n}=474$ ), which did not differ significantly ( $p>0.05$, Student's $t$-test) from the average size of bacteria associated with $\mathrm{AGG}_{0.2}$ $\left(0.46 \pm 0.02 \mu \mathrm{m}^{3} ; \mathrm{n}=181\right)$. The weighted average density of attached bacteria, determined for $\mathrm{AGG}_{0.8}$ collected in the August experiment, was $1.064 \pm$ $0.002 \mathrm{~g} \mathrm{~cm}^{-3}(\mathrm{n}=4)$. Note that this estimate has an error due to the inclusion of bacteria in either top

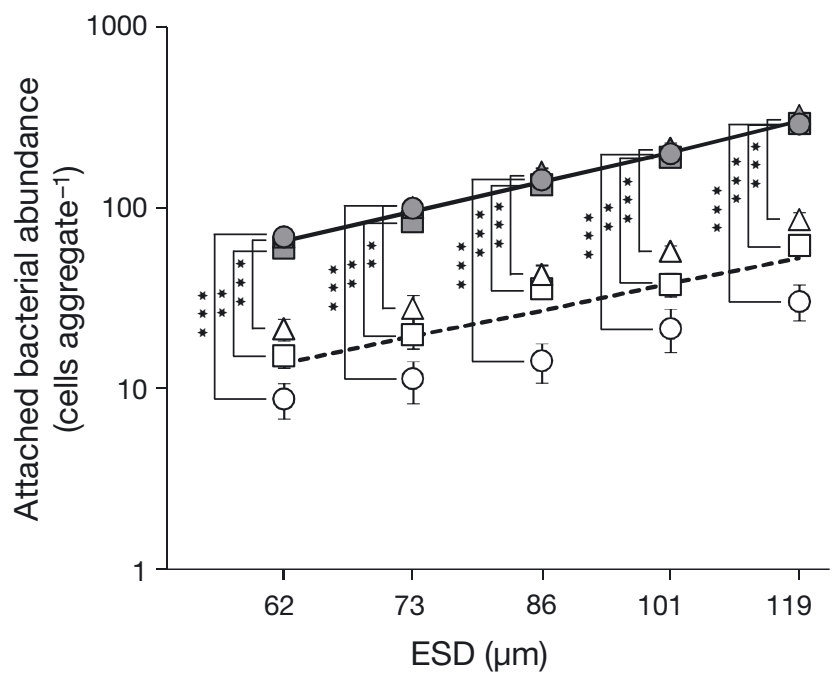

Fig. 3. Relationship between attached bacterial abundance and size (equivalent spherical diameter, ESD) of aggregates $\mathrm{AGG}_{0.8}$ ( $\square$ : January; $\Delta$ : August; $\mathrm{O}$ : November) and $\mathrm{AGG}_{0.2}$ ( $\square$ : January; $\triangle$ : August; $O$ : November). Values are means \pm $\mathrm{SE}_{\text {; }}$ error bars are those associated with 3 (January) or 4 (August and November) replicated bottles. For each bottle, 10 to 20 aggregates were analyzed. Asterisks indicate the significance of the difference between $\mathrm{AGG}_{0.8}$ and $\mathrm{AGG}_{0.2}\left({ }^{* *} \mathrm{p}<\right.$ $0.01,{ }^{* * *} \mathrm{p}<0.001$; Student's $t$-test). Solid and dashed lines are linear regressions after double logarithmic transformation for $\mathrm{AGG}_{0.8}$ and $\mathrm{AGG}_{0.2}$, respectively (see 'Results') or bottom fractions of the density gradient (these bacteria have densities either lower or higher than the analytical limits; see 'Materials and methods'). While the abundance of bacteria contained in the top fraction accounted for only $3.7 \pm 1.6 \%(n=4)$ of total attached bacterial abundance, the contribution of bacteria contained in the bottom fraction was relatively large $(38.1 \pm 7.1 \%[\mathrm{n}=4]$ of total attached bacterial abundance), suggesting that our estimate of average bacterial density might be too low.

The ranges of $W_{50}$ values for $\mathrm{AGG}_{0.8}$ and $\mathrm{AGG}_{0.2}$ were $0.0025-0.0054 \mathrm{~cm} \mathrm{~s}^{-1}$ and $0.0056-0.0136 \mathrm{~cm}$ $\mathrm{s}^{-1}$, respectively. For each size class, the $W_{50}$ values for $\mathrm{AGG}_{0.8}$ were lower (1.6- to 4.5-fold) than those of $\mathrm{AGG}_{0.2}$ (Fig. 4). The differences in the $W_{50}$ values between $\mathrm{AGG}_{0.8}$ and $\mathrm{AGG}_{0.2}$ were significant ( $\mathrm{p}<0.05$, Student's $t$-test), except for the 62, 73, and $86 \mu \mathrm{m}$ size classes in the August experiment (Fig. 4).

\section{Aggregate $\varepsilon$, enzyme activity, and morphological parameters}

The $\varepsilon$ of $\mathrm{AGG}_{0.8}$ and $\mathrm{AGG}_{0.2}$ varied in the ranges of $0.932-0.981$ and $0.719-0.929$, respectively. The average $\varepsilon$ of $\mathrm{AGG}_{0.2}$ was significantly smaller than the corresponding $\varepsilon$ of $\mathrm{AGG}_{0.8}$ for each size class $(\mathrm{p}<0.05$, Student's $t$-test, Fig. 5). Empirical equations that relate $\varepsilon$ to $D$ were obtained using a quadratic regression model after a double logarithmic transformation. A quadratic rather than linear regression model was used because the $r^{2}$ value of the quadratic regression exceeded that of the linear regression for both $\mathrm{AGG}_{0.8}$ and $\mathrm{AGG}_{0.2}$. The following regression equations were derived: $\log \varepsilon=1.214+(0.719 \times \log D)-$ $\left[0.166 \times(\log D)^{2}\right]\left(\mathrm{r}^{2}=0.73, \mathrm{p}<0.001, \mathrm{n}=20\right)$ for $\mathrm{AGG}_{0.8}$, and $\log \varepsilon=-2.704+(4.409 \times \log D)-[1.040$ $\left.\times(\log D)^{2}\right]\left(\mathrm{r}^{2}=0.76, \mathrm{p}<0.001, \mathrm{n}=20\right)$ for $\mathrm{AGG}_{0.2}$.

In the August experiment, the ectoenzymatic activity (hydrolysis rate of 4-MUF- $N$-acetyl- $\beta$-D-glucosaminide, mean $\pm \mathrm{SE}, \mathrm{n}=3$ ) of $\mathrm{AGG}_{0.8}$ and $\mathrm{AGG}_{0.2}$ was $4.00 \pm 0.99 \mathrm{nM} \mathrm{min}^{-1} \mathrm{ml}^{-1}$ and $0.03 \pm 0.01 \mathrm{nM}$ $\mathrm{min}^{-1} \mathrm{ml}^{-1}$, respectively, with the former being significantly ( $p<0.05$, Student's $t$-test) higher than the latter.

Results of morphological analyses of aggregates are tabulated in Table 1. Neither the long to short axis ratio nor the circularity differed significantly among different size classes for both $\mathrm{AGG}_{0.8}$ and $\mathrm{AGG}_{0.2}$ ( $\mathrm{p}>0.05$, ANOVA). The average long to short axis ratios for $\mathrm{AGG}_{0.8}$ and $\mathrm{AGG}_{0.2}$ were 0.596 

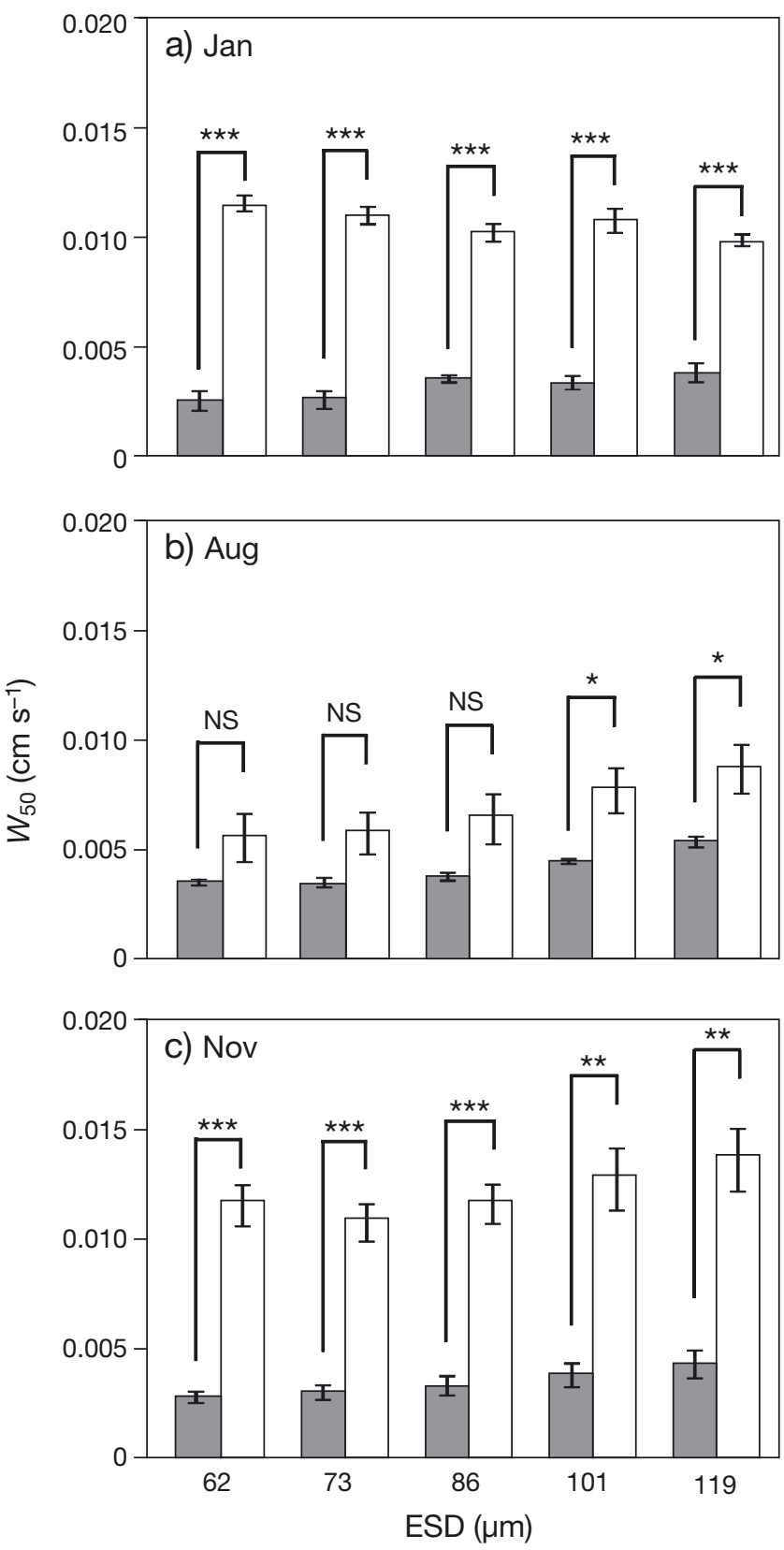

Fig. 4. Median settling velocity $\left(W_{50} ; \mathrm{cm} \mathrm{s}^{-1}\right)$ of each size class of aggregates $\mathrm{AGG}_{0.2}$ (gray bars) and $\mathrm{AGG}_{0.8}$ (white bars) in (a) January, (b) August, and (c) November experiments. Values are means \pm SE of 3 (January) or 4 (August and November) replicated bottles. Asterisks indicate the significance of the difference between $\mathrm{AGG}_{0.8}$ and $\mathrm{AGG}_{0.2}\left({ }^{*} \mathrm{p}<0.05,{ }^{* *} \mathrm{p}<\right.$ $0.01,{ }^{* * *} \mathrm{p}<0.001, \mathrm{NS}: \mathrm{p}>0.05 ;$ Student's $t$-test)

and 0.584 , respectively, which did not differ significantly from each other ( $\mathrm{p}>0.05$, Student's $t$-test). The average circularities for $\mathrm{AGG}_{0.8}$ and $\mathrm{AGG}_{0.2}$ were 0.072 and 0.044 , respectively. The former was significantly larger than the latter $(p<0.001$, Student's $t$-test).

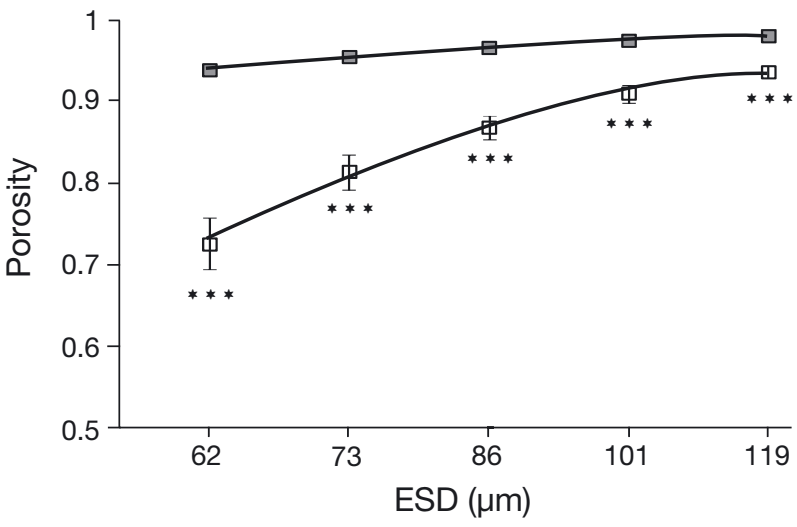

Fig. 5. Relationship between porosity and size (equivalent spherical diameter, ESD) of aggregates $\mathrm{AGG}_{0.8}$ (ם) and $\mathrm{AGG}_{0.2}(\square)$. Data were collected during the November experiment. Values are means \pm SE of 4 replicate bottles. Asterisks indicate the significance of the difference between $\mathrm{AGG}_{0.8}$ and $\mathrm{AGG}_{0.2}\left({ }^{* * *} \mathrm{p}<0.001\right.$; Student's $t$-test $)$ for each size class. Fitted curves are quadratic regressions after double logarithmic transformation (see 'Results')

\section{DISCUSSION}

\section{Use of model aggregates to examine aggregate settling velocity}

The model aggregates exhibited the key features of natural marine aggregates: they were spontaneously assembled micro-gels that are abundant in marine waters (Chin et al. 1998, Verdugo 2012); they were stainable by Alcian Blue, a critical feature that characterizes TEP (Alldredge et al. 1993); they contained sulfate and amino polysaccharides, which are the major constituents of TEP (Zhou et al. 1998, Passow 2002); and their monomeric constituents, fucose and glucosamine, are ubiquitous and can be abundant in marine waters (Borch \& Kirchman 1997, Myklestad et al. 1997). Furthermore, our experiments modeled the fundamental features of microbeaggregate interactions in marine systems, i.e. colonization, growth, and enzymatic cleavage of polymers (Azam \& Malfatti 2007, Nagata 2008). Ectoenzymatic activities cleaving fucoidan and chitin have been detected in seawater (Gooday 1990, Poulicek et al. 1998, Ziervogel \& Arnosti 2008), indicating that the model aggregates serve not only as attachment surfaces but also as carbon and nutrient sources for microbes. In fact, in our experiments, $\mathrm{AGG}_{0.8}$ were densely colonized by bacteria, with an abundance of 0.050 to 0.074 cells $\mu^{-2}$. This is within the higher range of bacterial abundance reported to be associated with marine TEP within a similar size range of aggregates $\left(0.006\right.$ to 0.079 cells $\mu^{-2}$; Schuster \& 
Table 1. Long to short axis ratio and circularity of aggregates $\mathrm{AGG}_{0.8}$ and $\mathrm{AGG}_{0.2}$. The data were collected during the January experiment. Values are means \pm SE of triplicate bottles $(n=3)$ for the different size classes. For each bottle, 40 to 71 particles were analyzed. ESD: equivalent spherical diameter

\begin{tabular}{|cccccccc|}
\hline & & \multicolumn{7}{c}{ ESD $(\mu \mathrm{m})$} & & & \multirow{2}{*}{ Mean $(\mu \mathrm{m})$} \\
\cline { 3 - 7 } & & 62 & 73 & 86 & 101 & 119 & \\
\hline Long to short & $\mathrm{AGG}_{0.8}$ & $0.586 \pm 0.007$ & $0.590 \pm 0.003$ & $0.623 \pm 0.002$ & $0.630 \pm 0.006$ & $0.551 \pm 0.011$ & $0.596 \pm 0.004$ \\
axis ratio & $\mathrm{AGG}_{0.2}$ & $0.614 \pm 0.005$ & $0.581 \pm 0.020$ & $0.600 \pm 0.006$ & $0.534 \pm 0.010$ & $0.593 \pm 0.012$ & $0.584 \pm 0.005$ \\
Circularity & $\mathrm{AGG}_{0.8}$ & $0.072 \pm 0.001$ & $0.066 \pm 0.001$ & $0.076 \pm 0.004$ & $0.076 \pm 0.004$ & $0.070 \pm 0.003$ & $0.072 \pm 0.001$ \\
& $\mathrm{AGG}_{0.2}$ & $0.055 \pm 0.001$ & $0.043 \pm 0.002$ & $0.041 \pm 0.001$ & $0.039 \pm 0.001$ & $0.040 \pm 0.001$ & $0.044 \pm 0.001$ \\
\hline
\end{tabular}

Herndl 1995, Mari \& Kiørboe 1996, Passow 2002). The average cell volume of bacteria associated with $\mathrm{AGG}_{0.2}$ was relatively large $\left(0.46 \mathrm{\mu m}^{3}\right)$ and differed little from that of $\mathrm{AGG}_{0.8}$, suggesting that a fraction of small bacteria initially contained in the $0.2 \mu \mathrm{m}$ filtered seawater became larger during their growth on the substrate-rich aggregates. The bacterial growth on $\mathrm{AGG}_{0.8}$ was accompanied by a substantial increase in ectoenzymatic activity, supporting the notion that bacteria cleaved polymer matrices during colonization and growth. Thus, our model aggregates represent a class of carbohydrate-rich aggregates that harbor dense bacterial communities. The following discussion will focus on the specific mechanisms underlying the regulation of model aggregate settling velocity.

\section{Possible mechanisms of the reduction of aggregate settling velocity via bacterial colonization}

The $W_{50}$ values for $\mathrm{AGG}_{0.8}$ were significantly (1.6to 4.5-fold) lower than those for $\mathrm{AGG}_{0.2}$. Settling velocities of $\mathrm{AGG}_{0.8}$ would have been affected by the adsorption of submicron-sized TEP that existed in the $0.8 \mu \mathrm{m}$ filtrate but not in the $0.2 \mu \mathrm{m}$ filtrate. Although submicron-sized TEP are known to be abundant in natural seawaters, their contributions to total TEP volumes are usually low $(<1 \%)$, with typical volume concentrations being on the order of 0.1 to $1 \mathrm{ppm}$ in coastal waters (Passow 2002). These typical submicron-sized TEP volumes may account for only a small fraction $(<1 \%)$ of the total volume concentration of the model aggregates in our experiments (97.5 ppm). Therefore, it is considered that the effects of the adsorption of submicron-sized TEP on the settling velocities of $\mathrm{AGG}_{0.8}$, if any, were minimal. Rather, we consider that our results, to the best of our knowledge, are among the first indicating that bacterial colonization of aggregates can result in a significant reduction in the settling velocity of similar-sized aggregates.
To examine the mechanisms underlying this reduction in settling velocity, we used the Stokes model (Oliver et al. 1981) as a theoretical framework to relate the aggregate settling velocity $\left(V, \mathrm{~cm} \mathrm{~s}^{-1}\right.$; hereafter, $W_{50}$ is referred to as $v$ for the theoretical considerations in this paragraph) to aggregate properties including size $(D$, the diameter of the particle in $\mathrm{cm})$, mean density $\left(\rho^{\prime}, \mathrm{g} \mathrm{cm}^{-3}\right)$, and morphology $(\varphi$, a dimensionless coefficient of form resistance):

$$
v=\frac{g D^{2}\left(\rho^{\prime}-\rho_{0}\right)}{18 \mu \varphi}
$$

where $g$ is gravitational acceleration $\left(\mathrm{cm} \mathrm{s}^{-2}\right), \mu$ is the viscosity of seawater $\left(\mathrm{g} \mathrm{cm}^{-1} \mathrm{~s}^{-1}\right)$, and $\rho_{0}$ is the density of seawater $\left(\mathrm{g} \mathrm{cm}^{-3}\right)$. Although this model does not perfectly describe the sinking of fractal organic aggregates in the sea (Logan \& Wilkinson 1990), it is useful for considering the different impacts of size, density, and porosity on aggregate sinking velocities (De La Rocha \& Passow 2007). Because our comparison of $V$ was made for aggregates belonging to the same size category (i.e. $D$ is the same), the difference in $v$ is ascribed to the difference in either $\rho^{\prime}$ (mean density difference) or $\varphi$ (morphological effects). For the density effect, there are at least 2 potential mechanisms by which attached bacteria can reduce $\rho^{\prime}$. First, bacterial growth may result in the replacement of a certain volume of polysaccharide matrices in aggregates by bacterial cells, which may then result in a reduction in $\rho^{\prime}$ (bacterial density is generally lower than polysaccharide density). Second, bacteria may increase the $\varepsilon$ of aggregates due to the cleavage of polymers. This results in the replacement of polysaccharide matrices by seawater, leading to a reduction in $\rho^{\prime}$ (seawater density is lower than polysaccharide density). These 2 factors can be considered by the following mass balance equations:

$$
\begin{gathered}
\rho^{\prime}=(1-\varepsilon) \rho_{\mathrm{S}}+\varepsilon \rho_{0} \\
\rho_{\mathrm{S}}=(1-\alpha) \rho_{\mathrm{pol}}+\alpha \rho_{\mathrm{bac}}
\end{gathered}
$$


where $\rho_{\mathrm{S}}\left(\mathrm{g} \mathrm{cm}^{-3}\right)$ is the density of the solid fraction consisting of polysaccharide matrices with a density of $\rho_{\text {pol }}\left(\mathrm{g} \mathrm{cm}^{-3}\right)$ and bacterial cells with a density of $\rho_{\text {bac }}\left(\mathrm{g} \mathrm{cm}^{-3}\right) . \varepsilon$ is the fraction of seawater volume relative to the total aggregate volume, and $\alpha$ is the fraction of bacterial cell volume relative to the total solid volume of the aggregate. Eqs. (2-4) can be rewritten as follows:

$$
v=\frac{g D^{2}(1-\varepsilon)\left[(1-\alpha) \rho_{\mathrm{pol}}+\alpha \rho_{\mathrm{bac}}-\rho_{0}\right]}{18 \mu \varphi}
$$

This model assumes that the aggregates are nonpermeable (there is no advective flow through the aggregates), which is consistent with the suggestion that marine aggregates have very low permeability (Ploug \& Passow 2007, Kindler et al. 2010). Clearly, this assumption does not hold for all aggregate types in marine environments. In fact, for fast-settling, large aggregates (with diameters on the order of a few $\mathrm{mm}$ ) containing ballast particles, apparent diffusivity within the aggregates has been reported to be high (Ploug et al. 2008). However, for the small (diameters 62 to $119 \mu \mathrm{m}$ ), slowly settling aggregates examined here, it is probably safe to assume that permeability barely influenced aggregate settling velocities (Logan \& Hunt 1987).

Using Eq. (5) and the parameters obtained in the present study $\left(\varepsilon, \alpha\right.$, and $\left.\rho_{\text {bac }}\right)$ and from the literature (Table 2), we examined the relative contribution of 2 effects of attached bacteria, i.e. $\alpha$ and $\varepsilon$, to the reduc- tion in the settling velocity of aggregates. Because the morphological effect $(\varphi)$ was unknown, we first estimated the $\varphi$ value for which the predicted $V$ becomes equal to the observed $v$ for each size category of $\mathrm{AGG}_{0.2}$. Then, the average $( \pm 1 \mathrm{SE}) \varphi$ for different size categories $(2.80 \pm 0.13, \mathrm{n}=5)$ was used as a parameter of the morphological effect for $\mathrm{AGG}_{0.2}$ (parameter set 1). Next, by assuming that $\varphi$ is constant $(=2.80)$, we determined to what extent the $v$ for $\mathrm{AGG}_{0.2}$ changes with increases in $\alpha$ and $\varepsilon$ to the levels that we determined for $\mathrm{AGG}_{0.8}$ (parameter sets 2 and 3). The results revealed that the increase in $\alpha$ (parameter set 2) resulted in only a $4.9 \%$ (range: 3.0 to $7.1 \%$ ) reduction in $v$ (Table 3 ), which explained a small fraction of the observed difference in $v$ between $\mathrm{AGG}_{0.8}$ and $\mathrm{AGG}_{0.2}(71.2 \%)$. Note that the extent of the reduction in $v$ with increasing $\alpha$ might be overestimated because our estimate of bacterial density would be too low (see 'Results'). In contrast, increases in both $\alpha$ and $\varepsilon$ (parameter set 3 ) resulted in a large reduction of $v$, with an average reduction of $75.4 \%$ (range: 74.4 to $76.4 \%$ ) (Table 3 ). These results indicate that the $\varepsilon$ effect was mainly responsible for the difference in $v$ between $\mathrm{AGG}_{0.2}$ and $\mathrm{AGG}_{0.8}$. Note that the predicted $v$ with parameter set 3 was slightly lower (by 0.9 to $6.3 \%$ depending on size categories) than the observed $v$ (Table 3). This might be due to differences in morphology (hence $\varphi$ ) between $\mathrm{AGG}_{0.2}$ and $\mathrm{AGG}_{0.8}$. Consistent with this notion, our results indicated that the circularity of $\mathrm{AGG}_{0.8}$ was larger

Table 2. Summary of the parameters used for the prediction of aggregate settling velocity $(v)$ according to the model described by Eq. (5). * Asterisks indicate the choice of parameters for each parameter set

\begin{tabular}{|c|c|c|c|c|c|c|c|}
\hline \multirow[t]{2}{*}{ Parameters } & \multirow[t]{2}{*}{ Units } & \multicolumn{4}{|c|}{ Parameter set } & \multirow[t]{2}{*}{ Values } & \multirow[t]{2}{*}{ Remarks } \\
\hline & & 1 & 2 & 3 & 4 & & \\
\hline$D$ & $\mu \mathrm{m}$ & * & * & ${ }^{*}$ & $*$ & $\begin{array}{c}62,73,86 \\
101,119\end{array}$ & Diameter of the aggregate \\
\hline$g$ & $\mathrm{~m} \mathrm{~s}^{-2}$ & * & * & $*$ & * & 9.8 & Gravitational acceleration \\
\hline$\mu$ & $\mathrm{kg} \mathrm{m}^{-1} \mathrm{~s}^{-1}$ & ${ }^{*}$ & * & $*$ & * & 0.00099 & Viscosity of seawater at $23^{\circ} \mathrm{C}$ and salinity 29 (Fofonoff \& Millard 1983) \\
\hline$\rho_{0}$ & $\mathrm{~g} \mathrm{~cm}^{-3}$ & * & ${ }^{*}$ & $*$ & * & 1.019 & Density of seawater at $23^{\circ} \mathrm{C}$ and salinity 29 (Fofonoff \& Millard 1983) \\
\hline$\rho_{\text {pol }}$ & $\mathrm{g} \mathrm{cm}^{-3}$ & * & * & $*$ & * & 1.6 & Density of polysaccharide matrices; Rickwood (1984), Harding (1995) \\
\hline$\rho_{\text {bac }}$ & $\mathrm{g} \mathrm{cm}^{-3}$ & * & * & $*$ & ${ }^{*}$ & 1.064 & $\begin{array}{l}\text { Density of bacterial cells, determined for bacteria } \\
\text { recovered from } \mathrm{AGG}_{0.8} \text { (see 'Discussion') }\end{array}$ \\
\hline$\varepsilon\left(\mathrm{AGG}_{0.2}\right)$ & - & * & * & - & - & $0.72-0.93$ & Porosity $(\varepsilon)$ for each size class was derived using the empirical \\
\hline$\varepsilon\left(\mathrm{AGG}_{0.8}\right)$ & & - & - & ${ }^{*}$ & $*$ & $0.93-0.98$ & relationship between $D$ and $\varepsilon$ (see 'Results') \\
\hline$\alpha\left(\mathrm{AGG}_{0.2}\right)$ & - & * & - & - & - & $0.002-0.004$ & $\alpha$ for each size class was calculated by dividing total bacterial \\
\hline$\alpha\left(\mathrm{AGG}_{0.8}\right)$ & & - & * & $*$ & $*$ & $0.036-0.080$ & $\begin{array}{l}\text { volume (= bacterial abundance derived using the empirical rela- } \\
\text { tionship between attached bacterial abundance and } D \times \text { average } \\
\text { bacterial cell volume) by total aggregate volume determined by } \\
\text { the Coulter counter method (see 'Results') }\end{array}$ \\
\hline $\begin{array}{l}\varphi\left(\mathrm{AGG}_{0.2}\right. \\
\left.\quad \text { or } \mathrm{AGG}_{0.8}\right)\end{array}$ & ) & * & * & * & - & 2.80 & Dimensionless coefficient of form resistance \\
\hline$\varphi\left(\mathrm{AGG}_{0.8}\right)$ & & - & - & - & ${ }^{*}$ & 2.42 & \\
\hline
\end{tabular}


Table 3. Summary of the observed and predicted aggregate settling velocity $(v)$ for the aggregates $\mathrm{AGG}_{0.8}$ and $\mathrm{AGG}_{0.2}$. Observed $v$ data were obtained from the November experiment for both $\mathrm{AGG}_{0.2}$ and $\mathrm{AGG}_{0.8} \%$ deviation: deviation between the observed $v$ and predicted $v$ for $\mathrm{AGG}_{0.2}$ \% reduction: reduction in the predicted $v$ of $\mathrm{AGG}_{0.8}$ compared to the predicted $v$ of $\mathrm{AGG}_{0.2}$. ESD: equivalent spherical diameter

\begin{tabular}{|c|c|c|c|c|c|c|c|c|c|c|c|}
\hline \multirow{2}{*}{$\begin{array}{l}\text { ESD } \\
(\mu \mathrm{m})\end{array}$} & \multicolumn{3}{|c|}{$-\mathrm{AGG}_{0.2}\left(\mathrm{~cm} \mathrm{~s}^{-1}\right)$} & \multirow[b]{2}{*}{ Observed } & \multirow[b]{2}{*}{$\begin{array}{c}\text { Reduction } \\
(\%)\end{array}$} & \multirow[b]{2}{*}{$\begin{array}{l}\text { Predicted } \\
\text { (parameter } \\
\text { set 2) }\end{array}$} & \multicolumn{2}{|c|}{$-\mathrm{AGG}_{0.8}\left(\mathrm{~cm} \mathrm{~s}^{-1}\right)$} & \multirow[b]{2}{*}{$\begin{array}{c}\text { Reduction } \\
(\%)\end{array}$} & \multirow[b]{2}{*}{$\begin{array}{c}\text { Predicted } \\
\text { (parameter } \\
\text { set } 4 \text { ) }\end{array}$} & \multirow[b]{2}{*}{$\begin{array}{c}\text { Reduction } \\
(\%)\end{array}$} \\
\hline & Observed & $\begin{array}{l}\text { Predicted } \\
\text { (parameter } \\
\text { set 1) }\end{array}$ & $\begin{array}{c}\text { Deviation } \\
(\%)\end{array}$ & & & & $\begin{array}{c}\text { Reduction } \\
(\%)\end{array}$ & $\begin{array}{c}\text { Predicted } \\
\text { (parameter } \\
\text { set 3) }\end{array}$ & & & \\
\hline 62 & 0.0115 & 0.0122 & -5.6 & 0.0028 & 75.6 & 0.0118 & 3.0 & 0.0029 & 76.4 & 0.0033 & 72.8 \\
\hline 73 & 0.0107 & 0.0124 & -15.0 & 0.0031 & 71.5 & 0.0119 & 3.8 & 0.0029 & 76.2 & 0.0034 & 72.5 \\
\hline 86 & 0.0116 & 0.0119 & -3.1 & 0.0033 & 71.6 & 0.0114 & 4.7 & 0.0029 & 75.4 & 0.0034 & 71.6 \\
\hline 101 & 0.0127 & 0.0113 & 10.6 & 0.0038 & 69.8 & 0.0107 & 5.8 & 0.0029 & 74.4 & 0.0034 & 70.4 \\
\hline 119 & 0.0136 & 0.0118 & 13.1 & 0.0043 & 68.4 & 0.0110 & 7.1 & 0.0030 & 74.7 & 0.0035 & 70.8 \\
\hline Mean & 0.0120 & 0.0119 & 0.8 & 0.0035 & 71.2 & 0.0113 & 4.9 & 0.0029 & 75.4 & 0.0034 & 71.6 \\
\hline
\end{tabular}

than that of $\mathrm{AGG}_{0.2}$. The difference between the predicted $v$ and the observed $v$ for $\mathrm{AGG}_{0.8}$ was minimized when $\varphi$ was 2.42 (parameter set 4 ; Table 3), yielding an average reduction value $(71.6 \%)$ close to the observed value $(71.2 \%)$.

The derivation of $\varphi$ and the examination of other parameters using the modified Stokes model (Eq. 5) have limitations, especially regarding the simplification of particle geometry. Our model lacks explicit representation of aggregate fractal dimension, which is an important geometric property influencing aggregate settling velocities (Logan \& Wilkinson 1990, Vahedi \& Gorczyca 2012). Keeping these limitations in mind, we stress that the estimated $\varphi$ would reflect not only the form resistance but also other hydrodynamic forces not examined here (Logan \& Wilkinson 1990). Nonetheless, the above results concerning the sensitivity of predicted $v$ to different parameter settings can be used to infer the principal mechanism by which $v$ was reduced as a consequence of bacterial colonization. We suggest that the increase in $\varepsilon$, due to bacterial enzymatic cleavage of aggregate matrices, was mainly responsible for the lower $v$ for $\mathrm{AGG}_{0.8}$ relative to $\mathrm{AGG}_{0.2}$. Bacterial cell volume $(\alpha)$ and morphology $(\varphi)$ also contributed to the change in $v$, although their contributions were not as large as that of porosity.

\section{Implications for material cycling in marine environments}

The aggregate settling velocities that we determined in the present study ( 0.003 to $0.014 \mathrm{~cm} \mathrm{~s}^{-1}$ ) are within the range of settling velocities reported in the literature for marine particles of similar size (approximately 50 to $100 \mu \mathrm{m})$ classes $\left(0.002\right.$ to $0.149 \mathrm{~cm} \mathrm{~s}^{-1}$; Fennessy et al. 1994, Christiansen et al. 2002, Xia et al. 2004). These particles, which are within the smaller size range of marine settling particles (Simon et al. 2002, McDonnell \& Buesseler 2012), are abundant in seawater and can account for a large fraction (up to $20 \%$ ) of total carbon sinking fluxes, as recently estimated for the subtropical Sargasso Sea (McDonnell \& Buesseler 2012). In addition, smaller sinking particles, especially sticky microgels, can serve as the precursors of larger aggregates (Verdugo 2012), indicating that changes in settling velocities of smaller particles can alter the depth-dependent patterns of larger aggregate formation in water columns. Considering the timescale of bacterial colonization and growth on fresh aggregates in the upper ocean (day) and the length scale of small aggregates settling at this timescale (10 to $100 \mathrm{~m})$, bacterial porosity enhancement can be an effective mechanism of suppressing the export of organic carbon and other bioelements to depth layers below the euphotic zone. We also note that changes in the porosity of aggregates due to attached bacterial action have implications for the regulation of fluid exchange between interstitial spaces and the ambient water in aggregates. Kindler et al. (2010) suggested that more porous aggregates can retain water for longer at density interfaces because of diffusion-limited fluid entrainment in the interstitial spaces of aggregates. Bacterial enhancement of aggregate porosity can be an important mechanism that promotes aggregate accumulation at density interfaces, a prominent phenomenon widely observed in oceanic environments (Alldredge \& Gotschalk 1988, MacIntyre et al. 1995). In addition, bacterial porosity enhancement may result in a higher retention of dissolved organic carbon in the interstitial spaces of aggregates, which may accelerate the downward delivery of dissolved organic carbon mediated by settling aggregates (Alldredge 2000). 
Natural aggregates in marine waters are complex and variable mixtures of organic and inorganic components. They are often composed of a variety of dense source particles, such as diatom frustules and dust (Ploug et al. 2008, Iversen \& Ploug 2010). Depending on the nature and compositions of the aggregates, the extent of bacterial effects on the aggregate settling velocities might deviate from the present results. For example, bacterial effects on the settling velocities would be less pronounced for the aggregates with a low content of polysaccharides and a high content of mineral particles because bacterial enzymatic cleavage of polymers may hardly modify bulk physical properties of such aggregates. It is important for future studies to examine the relationship between aggregate compositions and the extent and mechanisms of bacterial effects on aggregate settling velocities.

Acknowledgements. The present study was supported by the CREST project (awarded to K.K.) and JSPS KAKENHI Grant Number 24241003 (awarded to T.N. and H.F.). Y.Y. was supported by the Graduate Program for Leaders in Life Innovation (University of Tokyo).

\section{LITERATURE CITED}

Agrawal YC, Pottsmith HC (2000) Instruments for particle size and settling velocity observations in sediment transport. Mar Geol 168:89-114

Alldredge AL (1979) The chemical composition of macroscopic aggregates in two neritic seas. Limnol Oceanogr 24:855-866

Alldredge AL (2000) Interstitial dissolved organic carbon (DOC) concentrations within sinking marine aggregates and their potential contribution to carbon flux. Limnol Oceanogr 45:1245-1253

Alldredge AL, Gotschalk C (1988) In situ settling behavior of marine snow. Limnol Oceanogr 33:339-351

Alldredge AL, Passow U, Logan B (1993) The existence, abundance, and significance of large transparent exopolymer particles in the ocean. Deep-Sea Res I 140: $1131-1140$

Azam F, Malfatti F (2007) Microbial structuring of marine ecosystems. Nat Rev Microbiol 5:782-791

Borch NH, Kirchman DL (1997) Concentration and composition of dissolved combined neutral sugars (polysaccharides) in seawater determined by HPLC-PAD. Mar Chem 57:85-95

> Chin W, Orellana MV, Verdugo P (1998) Spontaneous assembly of marine dissolved organic matter into polymer gels. Nature 391:568-572

Christiansen C, Edelvang K, Emeis K, Graf G and others (2002) Material transport from the nearshore to the basinal environment in the southern Baltic Sea: I. Processes and mass estimates. J Mar Syst 35:133-150

Cowen JP (1992) Morphological study of marine bacterial capsules: implications for marine aggregates. Mar Biol 114:85-95
De La Rocha CL, Passow U (2007) Factors influencing the sinking of POC and the efficiency of the biological carbon pump. Deep-Sea Res II 54:639-658

Fennessy MJ, Dyer KR, Huntley DA (1994) An instrument to measure the size and settling velocity of flocs in situ. Mar Geol 117:107-117

Fisher NS, Nolan CV, Fowler SW (1991) Scavenging and retention of metals by zooplankton fecal pellets and marine snow. Deep-Sea Res A 38:1261-1275

Fofonoff NP, Millard RC Jr (1983) Algorithms for computation of fundamental properties of seawater. UNESCO Tech Pap Mar Sci 44

Gooday GW (1990) Physiology of microbial degradation of chitin and chitosan. Biodegradation 1:177-190

> Grossart HP, Berman T, Simon M, Pohlmann K (1998) Occurrence and microbial dynamics of macroscopic organic aggregates (lake snow) in Lake Kinneret, Israel, in fall. Aquat Microb Ecol 14:59-67

Harding SE (1995) Some recent developments in the size and shape analysis of industrial polysaccharides in solution using sedimentation analysis in the analytical ultracentrifuge. Carbohydr Polym 28:227-237

> Hoppe HG (1983) Significance of exoenzymatic activities in the ecology of brackish water: measurements by means of methylumbelliferyl-substrates. Mar Ecol Prog Ser 11: 299-308

> Inoue K, Nishimura M, Nayak BB, Kogure K (2007) Separation of marine bacteria according to buoyant density by use of the density-dependent cell sorting method. Appl Environ Microbiol 73:1049-1053

Iversen MH, Ploug H (2010) Ballast minerals and the sinking carbon flux in the ocean: carbon-specific respiration rates and sinking velocity of marine snow aggregates. Biogeosciences 7:2613-2624

Kindler K, Khalili A, Stocker R (2010) Diffusion-limited retention of porous particles at density interfaces. Proc Natl Acad Sci USA 107:22163-22168

> Logan BE, Hunt JR (1987) Advantages to microbes of growth in permeable aggregates in marine systems. Limnol Oceanogr 32:1034-1048

> Logan BE, Wilkinson DB (1990) Fractal geometry of marine snow and other biological aggregates. Limnol Oceanogr 35:130-136

Logan BE, Grossart HP, Simon M (1994) Direct observation of phytoplankton, TEP and aggregates on polycarbonate filters using brightfield microscopy. J Plankton Res 16: 1811-1815

> MacIntyre SA, Alldredge AL, Gotschalk C (1995) Accumulation of marine snow at density discontinuities in the water column. Limnol Oceanogr 40:449-468

> Mari X, Kiørboe T (1996) Abundance, size distribution and bacterial colonization of transparent exopolymer particles (TEP) in the Kattegat. J Plankton Res 18:969-986

Massana R, Gasol JM, Bjørnsen PK, Blackburn N and others (1997) Measurement of bacterial size via image analysis of epifluorescence preparations: description of an inexpensive system and solutions to some of the most common problems. Sci Mar 61:397-407

McDonnell AM, Buesseler KO (2012) A new method for the estimation of sinking particle fluxes from measurements of the particle size distribution, average sinking velocity, and carbon content. Limnol Oceanogr Methods 10:329-346

Myklestad SM, Skånøy E, Hestmann S (1997) A sensitive and rapid method for analysis of dissolved mono- and polysaccharides in seawater. Mar Chem 56:279-286 
Nagata T (2008) Organic matter-bacteria interactions in seawater. In: Kirchman DL (ed) Microbial ecology of the oceans, 2nd edn. John Wiley \& Sons, New York, NY, p 207-241

Nakamura S, Nambu M, Ishizuka T, Hattori H and others (2008) Effect of controlled release of fibroblast growth factor-2 from chitosan/fucoidan micro complex-hydrogel on in vitro and in vivo vascularization. J Biomed Mater Res A 85:619-627

Noble RT, Fuhrman JA (1998) Use of SYBR Green I for rapid epifluorescence counts of marine viruses and bacteria. Appl Environ Microbiol 14:113-118

Oliver RL, Kinnear AJ, Ganf GG (1981) Measurements of cell density of three freshwater phytoplankters by density gradient centrifugation. Limnol Oceanogr 26:285-294

Owen MW (1971) The effect of turbulence on the settling velocities of silt flocs. In: Sedimentation in estuaries and rivermouths. Proc 14th IAHR Congr, Paris, 4:27-32

Passow U (2002) Transparent exopolymer particles (TEP) in aquatic environments. Prog Oceanogr 55:287-333

Passow U, Alldredge AL (1994) Distribution, size, and bacterial colonization of transparent exopolymer particles (TEP) in the ocean. Mar Ecol Prog Ser 113:185-198

Passow U, Carlson CA (2012) The biological pump in a high $\mathrm{CO}_{2}$ world. Mar Ecol Prog Ser 470:249-271

Passow U, De La Rocha CL (2006) Accumulation of mineral ballast on organic aggregates. Global Biogeochem Cycles 20:GB1013, doi:10.1029/2005GB002579

Passow U, Shipe RF, Murray A, Pak DK, Brzezinski MA, Alldredge AL (2001) Origin of transparent exopolymer particles (TEP) and their role in the sedimentation of particulate matter. Cont Shelf Res 21:327-346

Ploug H, Passow U (2007) Direct measurement of diffusivity within diatom aggregates containing transparent expolymer particles. Limnol Oceanogr 52:1-6

Ploug H, Iversen MH, Koski M, Buitenhuis ET (2008) Production, oxygen respiration rates, and sinking velocity of copepod fecal pellets: direct measurements of ballasting by opal and calcite. Limnol Oceanogr 53:469-476

Porter KG, Feig YS (1980) The use of DAPI for identifying and counting aquatic microflora. Limnol Oceanogr 25: 943-948

Editorial responsibility: Gerhard Herndl, Vienna, Austria
Poulicek M, Gaill F, Goffinet G (1998) Chitin biodegradation in marine environments. In: van Bergen PF, Stankiewicz BA (eds) Nitrogen-containing macromolecules in the bio- and geosphere. American Chemical Society, Washington, DC, p 163-210

Rickwood D (1984) Centrifugation: a practical approach, 2nd edn. IRL Press, Oxford

Schuster S, Herndl GJ (1995) Formation and significance of transparent exopolymeric particles in the northern Adriatic Sea. Mar Ecol Prog Ser 124:227-236

Simon M, Grossart HP, Schweitzer B, Ploug H (2002) Microbial ecology of organic aggregates in aquatic ecosystems. Aquat Microb Ecol 28:175-211

Sterling MC Jr, Bonner JS, Ernest ANS, Page CA, Autenrieth RL (2004) Characterizing aquatic sediment-oil aggregates using in situ instruments. Mar Pollut Bull 48: 533-542

> Stoderegger K, Herndl GJ (1998) Production and release of bacterial capsular material and its subsequent utilization by marine bacterioplankton. Limnol Oceanogr 43: 877-884

> Sugimoto K, Fukuda H, Baki MA, Koike I (2007) Bacterial contributions to formation of transparent exopolymer particles (TEP) and seasonal trends in coastal waters of Sagami Bay, Japan. Aquat Microb Ecol 46:31-41

Vahedi A, Gorczyca B (2012) Predicting the settling velocity of flocs formed in water treatment using multiple fractal dimensions. Water Res 46:4188-4194

Verdugo P (2012) Marine microgels. Annu Rev Mar Sci 4: 375-400

Xia XM, Li Y, Yang H, Wu CY, Sing TH, Pong HK (2004) Observations on the size and settling velocity distributions of suspended sediment in the Pearl River Estuary, China. Cont Shelf Res 24:1809-1826

Zhou J, Mopper K, Passow U (1998) The role of surfaceactive carbohydrates in the formation of transparent exopolymer particles by bubble adsorption of seawater. Limnol Oceanogr 43:1860-1871

Ziervogel K, Arnosti C (2008) Polysaccharide hydrolysis in aggregates and free enzyme activity in aggregate-free seawater from the north-eastern Gulf of Mexico. Environ Microbiol 10:289-299

Submitted: May 13, 2013; Accepted: August 14, 2013

Proofs received from author(s): October 11, 2013 